\title{
FIRM COMPETITIVENESS GROWTH THROUGH VALUE CHAIN ACTIVITIES
}

\author{
Conf. univ.dr. Iuliana Ciochină, iulianaciochina@yahoo.com \\ "Constantin Brancoveanu” University Pitesti, \\ Faculty of Management, Marketing in Economic Affairs, Râmnicu Vâlcea \\ Lect. univ.dr. Carmen Iordache, iordache72@yahoo.com \\ "Constantin Brancoveanu" University Pitesti, \\ Faculty of Management, Marketing in Economic Affairs, Râmnicu Vâlcea \\ Asist. univ. drd. Răzvan Decuseară, dec vl@yahoo.com \\ “Constantin Brancoveanu” University Pitesti, \\ Faculty of Management, Marketing in Economic Affairs, Râmnicu Vâlcea \\ Asist. univ. drd. Ramona Chițu, ramona chitu 79@yahoo.com \\ “Constantin Brancoveanu” University Pitesti, \\ Faculty of Management, Marketing in Economic Affairs, Râmnicu Vâlcea
}

\begin{abstract}
Value chain shows the total value and is made up of value activities and value margin. Value activities are distinct activities from physical and technological point of view, developed by the firm. These are the "stones" with the help of which a firm creates a valuable product for its buyers. The value margin is the difference between total value and the collective cost of value activities.
\end{abstract}

In competition terms, value is the amount of money that buyers are willing to pay in return for what are being given by the company. Value is reflected in total income - price reflection of the firm product or of the product units that the firm can sell. A firm is profitable if the value it can obtain is higher than the costs involved in the product making. To create value for the buyers, higher than production and delivery costs, is the purpose of any generic strategy.

Value chain describes the entire range of activities that are necessary to bring a product or service from the setting up level, through different levels of production (involving a combination of physical transformations and different services utilization), delivery, to final the consumer, and doing away with it after using it. Value chain is an important construction in order to understand the way of distributing the obtained income from design, production, marketing, coordination and recycling.

Value chain shows the total value and is made up of value activities and value margin. Value activities are distinct activities from physical and technological point of view, developed by the firm. These are the "stones" with the help of which a firm creates a valuable product for its buyers. The value margin is the difference between total value and the collective cost of value activities. The value margin can be measured in different ways. The value chains of suppliers and distributors also include a value margin, whose separate identification is important in order to understand a firm's cost position sources, because this margin is a part of the total cost born by the buyer.

Value activities can be classified in two broad categories, according to Michael Porter: main activities and support activities. Main activities, represented in figure 1, are activities 
implied in the physical creation of the product, its selling and the physical transfer to the buyer, as well as the after - selling assistance. In any firm, main activities can be divided in the five generic categories indicated in figure number 1. Support activities help main activities and they help one another, by providing raw material, technology, human resources and ensuring different functions on the firm level.

Thus, value activities are the separate and distinct "stones" of competitive advantage. The way in which each activity is done, together with its economic laws, will decide whether a firm has low or high costs, besides its competitors. The way in which each activity is done will also determine its contribution to the buyer's needs, that is, also, the differentiation.

The comparison of competitors' value chains shows differences that determine competitive advantage.

Figure no. 1. Value chain of the company

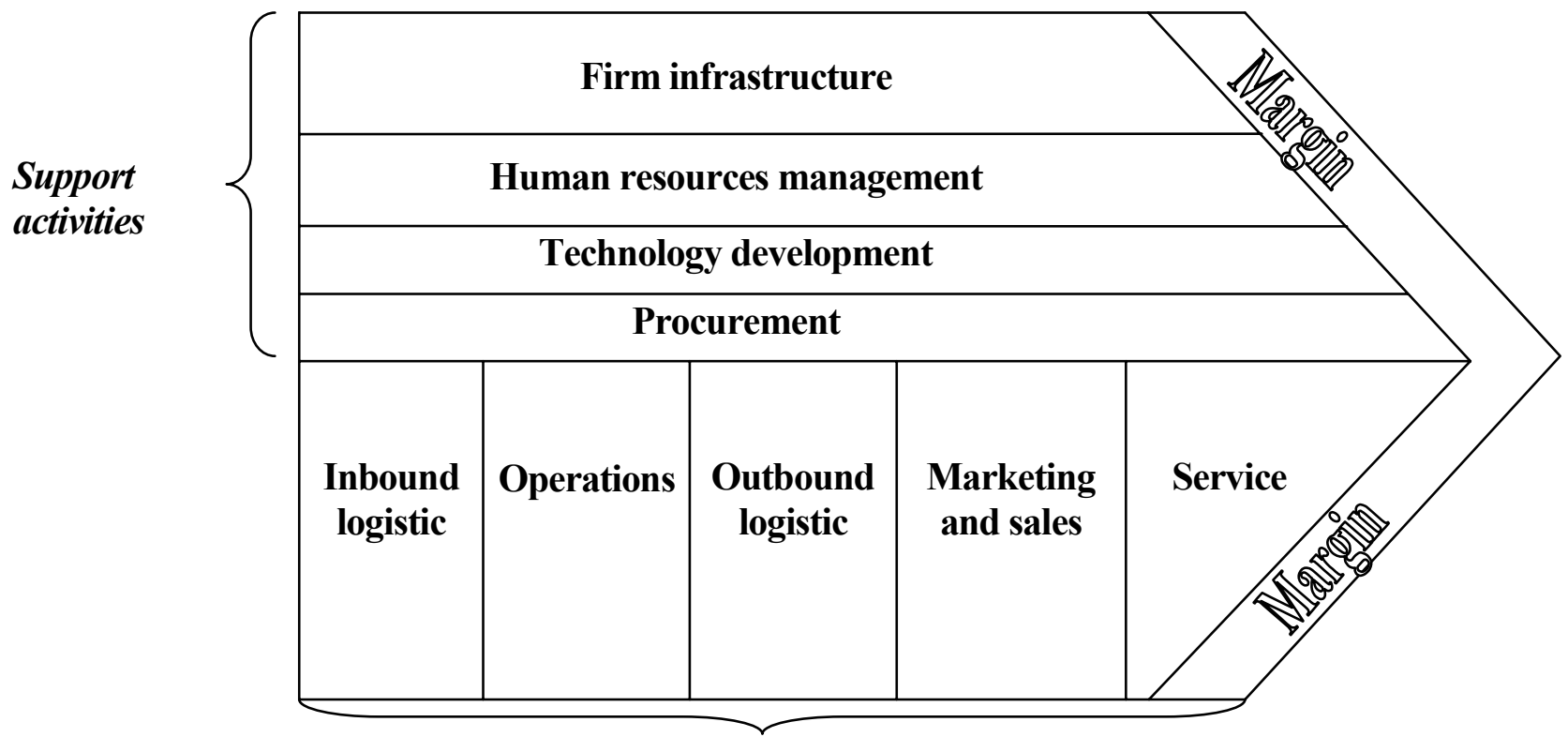

Primary activities

Source: Michael Porter, Avantajul concurențial. Manual de supraviețuirea şi de creştere a firmelor în condițiile economiei de piață, Editura Teora, Bucureşti, 2001, pag. 46.

\section{Main activities}

There are five generic categories of main activities involved by competition in any economic field, as presented in figure number 1. Each category can be divided in a number of distinct activities that depend on that field and on the firm's strategy:

Inbound logistics. Activities associated with the reception, storing and delivery of materials necessary to create the product, such as materials handling, storing, stocks financial administration, vehicles and returning to suppliers planning. 
Operations. Activities associated with raw materials turning into final products activities, such as processing, packing, assembling, installations maintaining, testing, and endowment exploitation operations.

Outbound logistics. Activities associated with taking, storing and physical delivery of the product to the buyers, such as final products storing, materials handling, delivery vehicles exploitation, orders taking and operations planning.

Marketing and sales. Activities associated with product delivery and buyers involving, such as advertising, promotion, sales staff, offers, channels choosing, relations with distributors and price setting up.

Service. Activities associated with service ensuring in order to increase or maintain the product value, such as installation services, repairs, training, supplying spare parts and product fixing.

\section{Support activities}

Value support activities that competition involves in any field can be divided in four generic categories, such as they presented in figure no. 1. As well as main activities, support activities can be subdivided in different value activities, characteristic to each field of activity.

Procurement refers to the purchasing function. Among purchased materials one can mention: raw materials, auxiliary production materials and other consumable articles, as well as assets such as equipments, laboratory installations, office devices and buildings.

Technology development. Every value activity involves technology in one way or another: know-how, proceedings or technology included in processing installations. The range of technologies used by most firms is very wide, starting with documents typing and goods transport, to technologies included in the product itself.

Technology development consists of a range of activities that can be divided in efforts of improving the product and the processing method. The development of the technology related to the product and to its characteristics supports the whole value chain, while, other types of technological development are associated to some specific activities, main or support activities.

Technology development is important for the competition advantage in all economic fields, in some of them even representing the competitive advantage key.

Human resources management. Human resources management consists in activities such as recruiting, employing, training and paying all types of staff. Human resources management encourages both main activities and individual support ones (for example: engineers employing), as well as the whole value chain (for example: labor contracts negotiation).

Human resources management influences the competitive advantage in any firm, through the role it plays both in determining professional competence and employees' motivation, as well as in determining employing and training costs. In some fields, it represents the key to competitive advantage.

Firm infrastructure. Firm's infrastructure consists in a number of activities that involve general management, planning, financial management, accountancy, legal assistance, relations with state authorities and quality management; unlike other support activities, it usually encourages the whole value chain, not individual activities.

\section{Types of activities}

Within every category of main and support activities there are three types of activities that play a different role in the strategic competitive advantage: 
- Direct. Activities directly involved in creating value for the buyer, such as assembling ones, components processing, sales staff use, advertising, product projecting, recruitment, etc.

- Indirect. Activities that make possible direct activities continuously, such as maintaining ones, planning, endowments exploiting, sales staff management, research studies administration, recording suppliers.

- Quality assuring. Activities that assure other activities quality, such as supervision ones, inspecting, testing, revision, checking, adjusting and re-processing. Quality assuring is not synonymous with quality management, because many value activities contribute to quality.

Within this context, a value chain analysis is a very important element that allows the following characteristics observation:

- it studies competitiveness nature and determinants, having a special contribution to the orientation towards inter-connected groups of firms;

- concentrating on all chain links (not only on production) and on all activities in every link helps to identify activities that are responsible of incomes growing and those that contribute to their decrease;

- as a result of these differences referring to the nature of income along various links within the chain, deciding people obtain clear information, necessary to formulate correct strategies and to take proper decisions. Thus, according to these decisions one can improve the activity in a chain link in order to generate higher incomes;

- with the help of this analyses one can prove that even if a firm is competitive, its connection to the world economy can require a certain concentration on macro-policies and institutional relations;

- participation on global markets, competitive at one time, cannot assure incomes increase in time. Concentrating on the way involved by this participation, value chain analysis allows the firm's incomes determinants understanding.

Competitive advantages result from the firm's ability to perform the required activities, either at lower costs, or in ways able to create value for the client and that allow the firm to ask for a higher price. In order to examine the ways through which a firm can obtain and support a competitive advantage, it is necessary to observe, individually, the activities generating value, along the value chain.

Competitive advantages require that the value chain of a firm to be rather a system than a collection of separates parts. Value chain reconfiguration or the elimination of activities lays sometimes at the base of major improvements of the competitive position. A firm is profitable if its value is higher than the total costs of performing all activities. In order to gain competitive advantages higher than its competitors, a firm must either provide a similar value to its client, or perform the activities in a unique way that create a higher value for the client that allows the firm to ask for a better price - differentiation.

The firm may claim to have a competitive advantage gained long its value chain only when its customers see the value provided by the firm as superior to that offered by its competitors.

The chain coordinator has also an important role within the value chain, who must continuously see to value obtaining all along the chain.

The differences between value chains of competitors are a main source of competitive advantage. 
Looking for sustainable competitive advantage, the firm should not limit only to its own value chain, but it also should have in view the value chains of suppliers, distributors and, finally, of its customers. Thus value supplying network takes form, which consists in the firm, suppliers, distributors, and, finally, customers, that form a "partnership" with one another in order to improve the whole system performance.

More firms today make up "partnerships" with other members of the offer chain in order to improve the performance of the value supplying network for the customer.

Competition today does no longer take place among individual competitors. It rather appears among whole networks of supplying value, created by these competitors. Firms do no longer compete among themselves through themselves, but through their marketing networks.

\section{Bibliography:}

1. Băcanu Bogdan, Practici de management strategic, Editura Polirom, Bucureşti, 2006.

2. Ciobanu Ioan, Management strategic, Editura Polirom, Bucureşti, 1998.

3. Danciu Victor, Marketing strategic competitiv. $O$ abordare internațională, Editura Economică, Bucureşti, 2004.

4. Kaplinsky Raphael, Morris Mike, $A$ handbook for value chain research (Internet source).

5. Kotler Philip, Armstrong Gary, Principiile marketingului, Ed. Teora, Bucureşti, 2003.

6. Kotler Philip, Managementul marketingului, Ed. Teora, Bucureşti, 2003.

7. Porter Michael, Avantajul concurențial. Manual de supraviețuirea şi de creştere a firmelor în condițiile economiei de piață, Editura Teora, Bucureşti, 2001. 